Article

\title{
The Ganges and the GAP: An Assessment of Efforts to Clean a Sacred River
}

\author{
Priyam Das ${ }^{1, *}$ and Kenneth R. Tamminga ${ }^{2}$ \\ 1 University of Hawaii at Manoa, Saunders 109, 2424 Maile Way, Honolulu, HI 96822, USA \\ 2 Penn State University, 121 Stuckeman Family Building, University Park, PA 16802, USA; \\ E-Mail: krt1@psu.edu
}

* Author to whom correspondence should be addressed; E-Mail: priyam@hawaii.edu; Tel.: +1-808-956-5367; Fax: +1-808-956-6870.

Received: 2 June 2012; in revised form: 16 July 2012 / Accepted: 18 July 2012 /

Published: 27 July 2012

\begin{abstract}
For centuries, the Ganges River in India has been the locus of sacred rites for the Hindus. The religious significance of the Ganges is physically manifested in ghats (stepped landings) that form the land-water interface. Besides serving as a site for religious bathing and cremation, the ghats are also tied to people's livelihoods and are an inseparable part of their daily lives. Today, the increasingly urbanized Ganges basin sustains more than 40 percent of India's population. At the same time, industrialization and the pressures of a growing population along its banks have contributed to alarming levels of pollution in the river. In 1985, the federal government of India launched the Ganga Action Plan (GAP) with the primary objective of cleaning the river. However, characterized by centralized planning and control with little public participation, the GAP had limited impact. In 2011, the government launched yet another clean up program - the National Ganga River Basin Project-with support from the World Bank. In this paper, we take a closer look at the programs to highlight the tenuous relationship between the need for 'efficient' management of environmental problems and public participation. Can public participation fit into the technocratic model that is often adopted by environmental programs? What approaches to participation kindle authorship and empowerment among those who share a deep relationship with the river and the ghats? Can religious practices be accommodated within scientific frameworks of adaptive management and resilience? We argue that rethinking the relationship between pollution control programs and participation is crucial for any effort to clean the Ganges, restore its waterfront, and catalyze broader regeneration in the Ganges basin.
\end{abstract}


Keywords: Ganges River; Ganga Action Plan; pollution control; participation; India; riparian urbanism; sustainability

\section{Introduction}

The river Ganges (or Ganga as it is known in India) has been the cradle of civilization in the Indo-Gangetc plains of northern India for several thousand years. Today, it sustains 43 percent of India's population. The Ganges basin is among the most heavily populated areas in the world with an average density of 520 persons per square kilometer [1]. Not only is the river a vital resource for agriculture and industry, it also holds an iconic status in India's cultural heritage. However, post-independence, the relentless push to modernize was accompanied by massive expansion of industry, urbanization and pressures of population growth. In the process, this invaluable resource was reduced to a convenient means of waste disposal [2,3]. Municipal sewage is a major culprit followed by industrial effluents and agricultural run-off. The river is also a site for religious bathing, washing and watering of animals, and the disposal of human and animal corpses. To tackle the escalating problem of pollution, the Government of India (GoI) has launched ambitious programs such as the Ganga Action Plan (GAP). Such programs, however, have had little success in meeting projected goals. An over-reliance on conventional approaches, conceived and implemented by the central government without the participation of local stakeholders [4], has contributed to the GAP's shortcomings. Moreover, superimposing a technocratic approach to pollution control on a vast, multi-faceted community which has its own cultural and religious understandings of pollution has produced a different set of results than that envisioned by the programs [5].

In this paper, we analyze efforts to control pollution in the Ganges from the perspective of (i) recent shifts in the policy arena, which call for decentralization and citizen participation; and (ii) the new paradigm in water resources management that recognizes river basins as large, complex, integrated ecological systems, promotes a shared concern for ecosystems health and human health, and acknowledges the interactions between urban dwellers and hydrological processes at multiple scales. We argue that pollution control programs in a culturally sensitive context like that of the Ganges will need to move beyond a top-down, technocratic approach towards one that creates inclusive spaces for collaboration and public participation to help bridge the gap between science and the sacred. Such an approach will need to be anchored on the premise that people's relationship with the Ganges is central to any effort to restore the river's health. We begin with a theoretical framework for analyzing pollution control programs. The framework emphasizes the benefits of decentralization and calls for a more nuanced approach to water resources management given its complexity. This is followed by a discussion about past efforts to clean the Ganges such as the GAP, highlighting where such efforts fell short. We then delineate how decentralization and public participation could contribute to the overall goals of improving water quality and environmental protection, which are essential to sustain people's deep-seated relationship with the river. The paper is based on fieldwork conducted in Varanasi to assess the GAP (January 2000) and on secondary research in the light of recent developments. Fieldwork included in-depth interviews with government officials, key representatives from 
non-governmental organizations (NGOs) and the local media, a brief survey of waterfront users, as well as site observations along the ghats of Varanasi and in its urban regional context. Secondary research involved a review of project documents and website, publications, and newspaper archives.

\section{Theoretical Framework}

Efforts to clean the Ganges have, so far, fallen far short of their stated goals. A critical analysis of the factors responsible for the shortcomings of the GAP underscores the fact that any large-scale pollution abatement program conceived at the macro-level requires not just collaboration with local institutions but also capacity building and public participation to adequately deal with diffuse sources of pollution. It cannot simply be imposed from the top. The theoretical framework presented in this section highlights the institutional aspects of the recent shift from 'government' to 'governance'. Focusing on decentralization and participatory water governance, this framework helps to analyze the GAP and the management of the Ganges river basin.

Centralized planning has been the norm in water resources management in India for several decades. However, municipalities have found this to be problematic, particularly when it concerns pollution control programs. They are strapped for revenue to operate and maintain large sewage disposal and treatment infrastructure controlled and financed by the central government. Over the last couple of decades, new forms of urban governance have called for decentralization resulting in the transfer of responsibilities from the state to local or community institutions. The rationale behind this shift is that decentralization would:

- ensure efficiency and equity by bringing decision making closer and making it more accountable to local populations [6,7];

- increase the proximity between political representatives and citizens, enabling better mobilization and efficient allocation of resources at the local level;

- stimulate creative, innovative, and responsive programs that are locally driven, and;

- present opportunities for citizens to participate in decision-making [8-10].

However, administrative and political decentralization are not always accompanied by fiscal decentralization, making it difficult for local governments to carry out their responsibilities. Moreover, the benefits of decentralization can fall prey to élite capture [11], and disempowered or vulnerable groups may be shut out of the process. Decentralization is effective where there is a vibrant civil society to ensure accountability [12]. It creates space for citizen participation in local governance [13] and a sense of ownership of decisions [14]. At the same time, critics have pointed out that participation, though well intentioned, often fades somewhere between rhetoric and action [5,15]. It can also disenfranchise marginalized groups by 'manufacturing' consensus on policies and strategies, without taking into account alternative, often competing, perspectives [13]. Others have pointed out how attempts to implement decentralization are driven by the need to report successes through indicators of predetermined outcomes separating participation from politics, which often results in the creation of participatory structures although actual decision-making happens somewhere else [15]. Consequently, the process of building local institutions that are accountable to the public is undermined in favor of identifying successes and retaining control $[15,16]$. 
Environmental resource management is well supported by "decentralization from below" since it is physically tied to a local context and has a history of everyday management and use [17]. However, it is important for grassroots constituents to exert pressure, since local governments often prioritize resource exploitation for economic development. Integrating the management of larger hydro-ecological systems with decentralization can be challenging. It requires the setting up of federations of local governments at a regional level [18]. Civil society representatives play a crucial role in ensuring that such regional committees are downwardly accountable [18]. Collaboration between civil society and local governments makes decentralization more effective. At the same time, it is important to keep civil society in check through representative authorities [16,19].

River basin and water management professionals have also called for a shift in management approaches. Earlier, water resource management was based on an ethic of exploitation where the goal was to achieve the most effective water allocation among users. However, the environmental movement of the 1970s questioned such approaches, pointing out how they conveniently ignored the interaction among various resource characteristics that created 'wicked problems' [20] for environmental managers. This brought into focus resource conservation and sustainable management. The new paradigm recognizes river basins as large, complex, integrated ecological systems, and promotes a shared concern for ecosystems health and human health. New approaches to managing water such as integrated water resource management and adaptive management [21,22] have acknowledged the interactions between humans and ecosystems. Integrated Water Resources Management (IWRM) is defined as "the coordinated development and management of water, land and related resources, in order to maximize the resultant economic and social welfare in an equitable manner without compromising the sustainability of vital ecosystems" [23]. The focus is, therefore, on facilitating participatory and inclusive practices $[24,25]$. This is in contrast to conventional approaches, which tend to employ linear, technocratic, problem-solving that relies heavily on engineered solutions. It generally discourages public participation in the interests of promoting efficiency and the dominance of experts in decision-making $[15,16]$. Resource managers are expected to work on time bound and rigid targets and often end up relying on reductionist management models [26]. However, critics have pointed out that the IWRM framework is difficult to operationalize [27]. According to Biswas [27], the concept is still ambiguous and does not clearly articulate what and how aspects of water resources management should be integrated, nor by whom. Moreover, integration from an institutional perspective could even be counterproductive, as it could result in re-centralization and reduced responsiveness to stakeholder needs. Improving the management of water resources calls for "close collaboration, cooperation, and coordination" among institutions, public and private, associated with their management, rather than integrated management $[27,28]$.

\section{A Sacred River Desecrated}

The Ganges river system is one of the largest in the world. It originates near the Gangotri glacier in the Himalayas and flows $2525 \mathrm{~km}$ from its headwaters to the Bay of Bengal (Figure 1). It accounts for 25 percent of India's water resources. In recent years, the increasing demand for agricultural production and the growing urban centers in the basin have been exerting immense pressure on this resource. A large proportion of Ganges water is diverted into the Upper and Lower Ganges canals to 
support agriculture, reducing flows in the main river. Although various tributaries replenish the river to a certain extent as it flows downstream, the reduced flows, particularly during the lean months (January-May), have diminished water quality as pollutants become concentrated, impairing ecological communities and exceeding bathing standards. This is apparent in cities like Varanasi where pollution levels are often found to be higher during these months. While beyond the scope of this paper, other scholars (for example, [29]) have examined the looming impact of climate change on water quantity and quality of the Ganges basin. This imminent threat will compound the serious problems with which urban populations and institutions in the Ganges basin are already struggling.

Figure 1. The Ganges Basin, India [30].

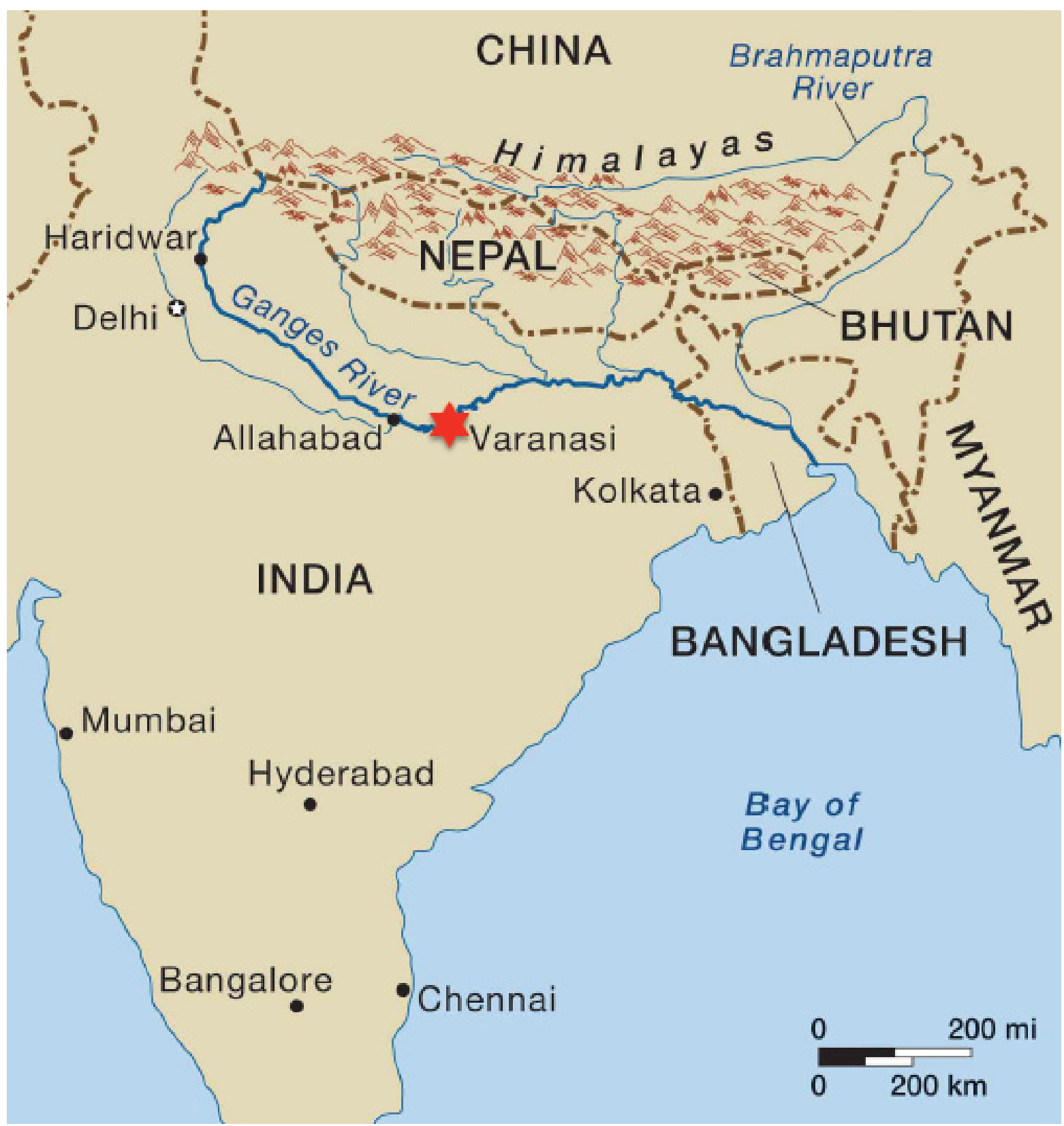


Varanasi, also known as Kashi (the city of light) to the Hindus, sits on the western bank of the Ganges. It is one of the seven sacred cities or tirthas (crossings or fords) where Hindus can find moksha (spiritual liberation) [31]. The city's waterfront is lined with ghats, which are symbolically associated with the passage from life to death or life hereafter [32]. Devout worshippers gather at the ghats every morning to take a holy dip in the hope of attaining moksha. The city is reputed to be a seat of spiritual education. Sages and pilgrims have come here to teach and to study the Vedas (a collection of Hindu religious texts) [31]. Unlike many other cities in India, Varanasi has retained much of its old character. Even today, the ghats bustle with activity. Multitudes of Hindus from across India come here on a spiritual odyssey - to bathe in the river and drink its holy water. It is also the last resting-place for the dead, whose cremated ashes are immersed in the river for spiritual rebirth [33]. The area between the tributaries, Varuna and Assi (from which the city's name is derived), mark the sacred limits where moksha is guaranteed to those who die or are cremated there [34]. The Hindus also believe in the purifying qualities of the Ganges, carrying away jars filled with its water, which is used for religious rituals. Livelihoods thrive along the ghats as pandas (brahmin priests who officiate religious rituals), ghatias (brahmins who oversee ghat rituals), and pujaris (brahmin priests in charge of worship in the temples) offer their services to pilgrims [31] and vendors sell everything from flowers and oil lamps to Coca Cola for thirsty travelers. Dhobis (washermen) use the waterfront to wash clothes while the yadavs (milkmen) bring their water buffaloes to bathe in the river (Figure $2(\mathrm{a}, \mathrm{b})$ ).

Figure 2. (a) The Dashashwamedha ghat in Varanasi; (b) The Lal ghat in Varanasi.

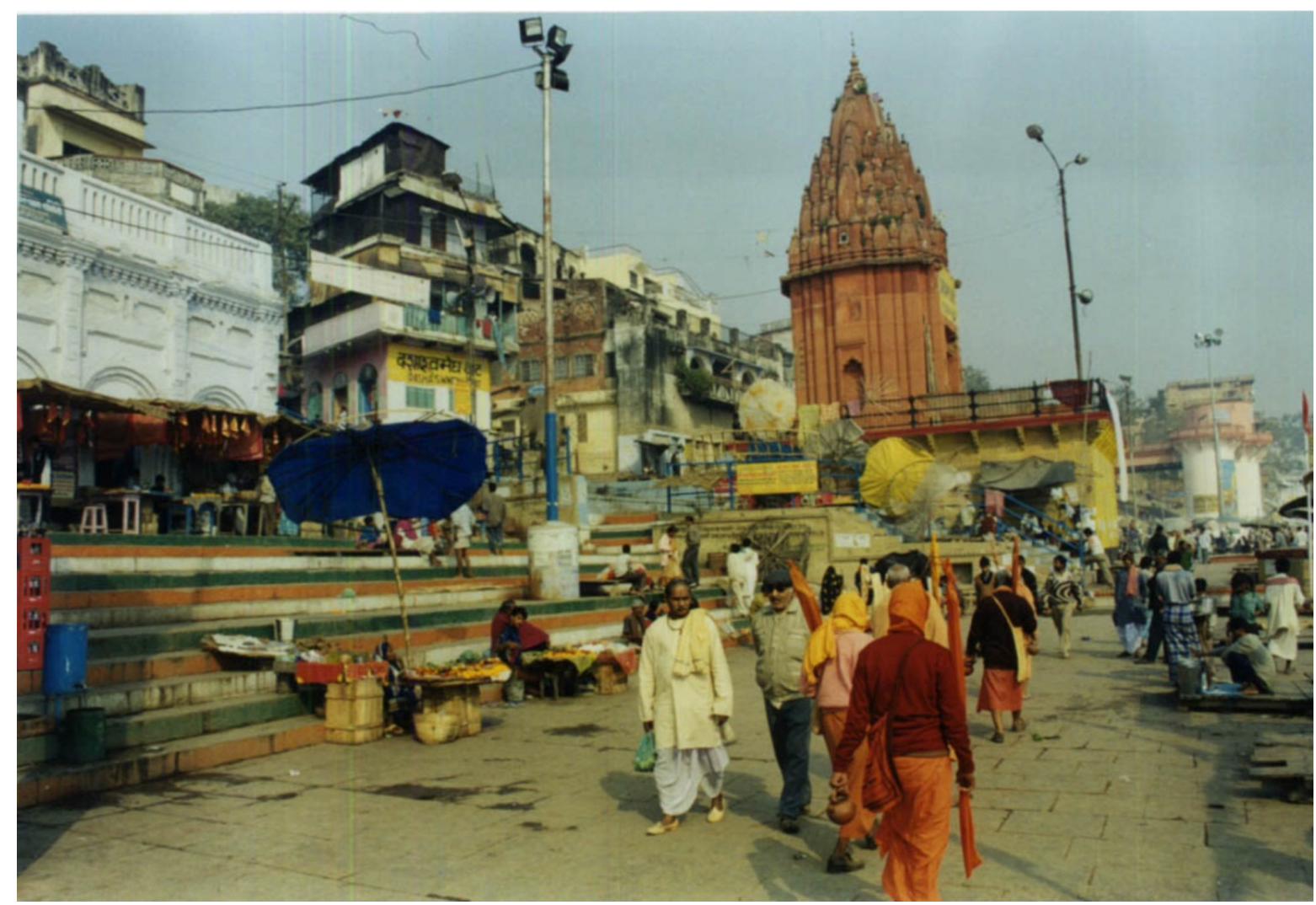

(a) 
Figure 2. Cont.

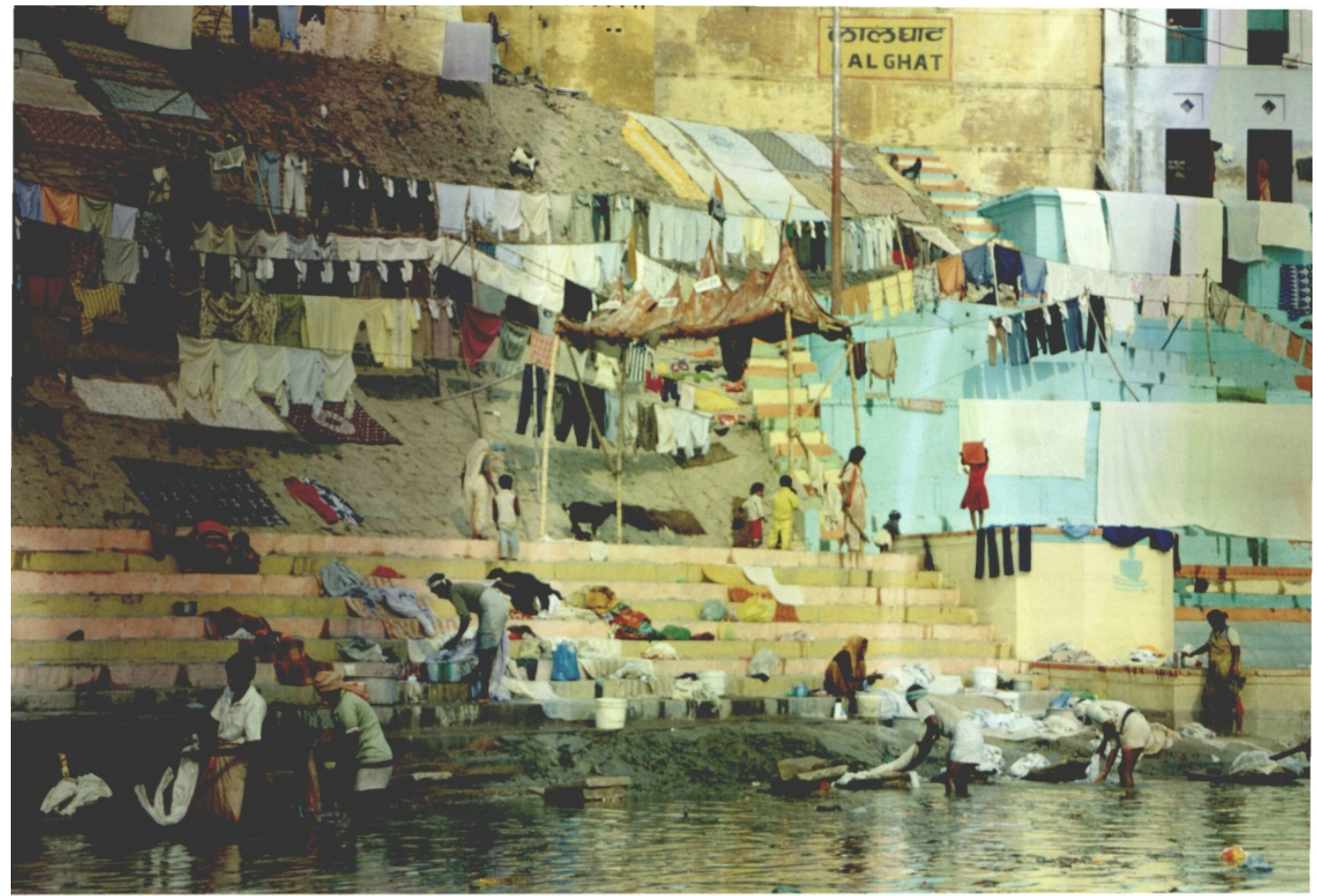

(b)

Figure 3. Raw sewage flows into the Ganges in Varanasi.

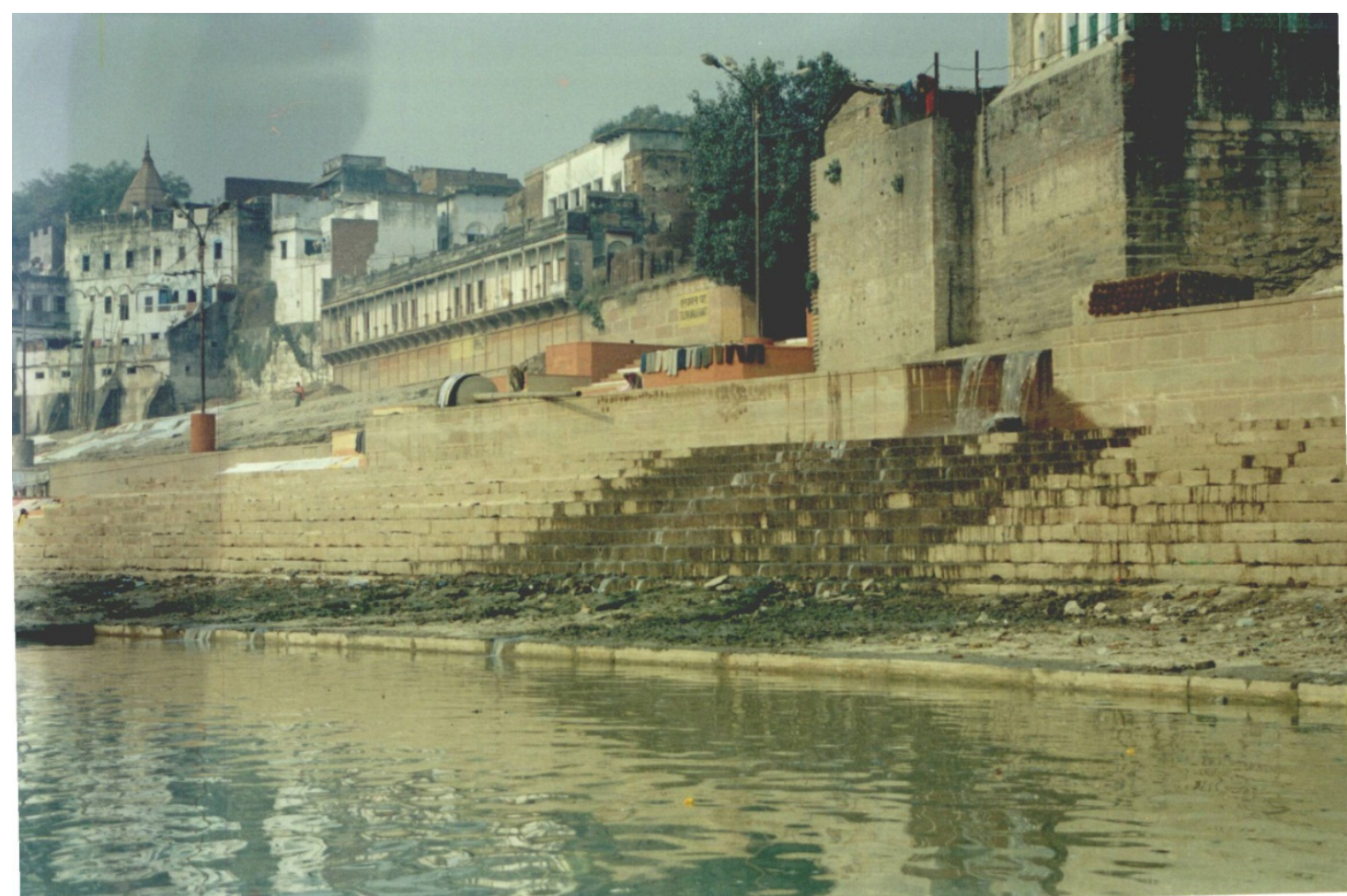

At the same time, the pressures of urbanization have begun to take a toll on the city and its holy river. Over the years, city master plans have fallen by the wayside due to changing politics and lack of implementation resources. Sewage systems, built during the colonial era, are grossly inadequate in 
meeting the demands of a growing city. Much of the city's sewage and industrial waste flows untreated into the river, alongside religious bathing. According to the Central Pollution Control Board (CPCB) of India, the main sources of pollution are urban sewage (Figure 3), industrial liquid waste, large scale bathing of cattle, throwing of dead bodies in the river, and surface run-off from solid waste landfills and dumpsites [35]. The Swatcha Ganga Research Laboratory in Varanasi, which conducts regular water quality tests, found that fecal coliform counts (FCC) range between 16,000 to 60,000 mpn per $100 \mathrm{~mL}$ of water from the bathing ghats, which far exceeds the permissible limit (limit for bathing is $500 \mathrm{mpn}$ per $100 \mathrm{~mL}$ as stipulated by the CPCB) [36]. Similarly, biological oxygen demand (BOD) values are much higher $(4.4$ to $7.6 \mathrm{mg} / \mathrm{L})$ than the water quality standard of less than $3 \mathrm{mg} / \mathrm{L}$ for bathing, particularly between Kannauj and Varanasi [37]. Tanneries, chemical plants, textile mills, distilleries and slaughterhouses discharge untreated liquid waste into the river through open drains and canals. Water users are exposed to this pollution and face a high risk of waterborne diseases [38].

The great paradox is that the sense of "river" in India is so intricately interwoven with belief systems and symbolism that it becomes difficult to disentangle sacred and secular concerns [39]. We conducted a brief survey along the Ganges waterfront in Varanasi to assess people's relationship with the river. Our sample included pilgrims, priests, and residents $(n=50)$. Participants were asked about their perception of pollution in the Ganges and about the GAP-I. We also conducted interviews with key informants (government officials, religious leaders, NGO representatives, and academics). Most of these interviews were open-ended. Activities along the waterfront were recorded on site plans. Maps and newspaper clippings were an important source of information. We also used photo-documentation to record spatial pattern and cultural activities along the ghats. Our data revealed that those who depend on the Ganges for spiritual sustenance speak of "pollution" in terms of sacred impurity associated with declining social and religious values. They refer to the Ganges as "mother" and "purifier", establishing strong cultural ties with the river. They invoke the Ganges' purifying power through the practice of snan-religious ablutions, meditation, and worship. Some respondents did acknowledge the problems associated with pollution due to an expanding city. However, they did not undermine the cleansing powers of Gangaji. During a semi-structured interview, one resident responded, "Gangaji can never be impure because she has the ability to cleanse herself" [40]. In contrast, GAP officials define pollution in technical terms such as fecal coliform count, biological oxygen demand, and dissolved oxygen. Clearly, there is a disjunction between the two perceptions of pollution. The residents of Varanasi and the pilgrims who travel to this holy city from far-flung places are hardly dissuaded by the fact that coliform bacteria levels in the river are dangerously high [3]. Their spiritual bond with the river remains strong even today and their faith in the healing properties of the Ganges continues to bring them to the ghats. In January 2001, an estimated 7.5 million people bathed in the Ganges at the Maha Kumbh Mela, a religious congregation that occurs every 12 years. The festival was held in Allahabad at the confluence of the Ganges, Yamuna, and Saraswati rivers known as the sangam, which is associated with very high religious merit. At the same time, changes in water quantity and quality in the Ganges basin have witnessed mounting tension among stakeholders trying to protect their interests. 


\section{Pollution Control Programs for the Ganges}

The birth of the Ganga Action Plan (GAP) can be linked to public outrage regarding pollution. In 1985, environmental lawyer M.C. Mehta filed a public interest litigation in the Supreme Court of India holding the government and industries responsible for the alarming rise in pollution in the Ganges. The Ganga Pollution Cases ultimately resulted in pollution fines and the closure of several industries that were found guilty of not complying with environmental legislation [41]. That same year, the Central Ganga Authority (CGA) was created within the Department of Environment. The CGA developed the GAP, a massive program designed to control pollution in the Ganges and its tributaries. The objective was to establish a series of sewage treatment plants near the main urban centers, renovate all existing sewage pumping and treatment stations, provide wastewater sub-pumping stations at the mouths of open drains not yet linked to existing sewer systems, expand existing sewer networks by connecting unserviced areas, and construct electric crematoriums to address the issue of improperly cremated human remains along the ghats [41].

The CGA was responsible for the implementation of the GAP and for establishing future policies and programs. It was later renamed the National River Conservation Authority (NRCA) and it identified 18 other major rivers in 10 states of India that were facing pollution problems similar to that of the Ganges. Plans were also formulated for controlling pollution in these other rivers [42]. Although the GAP I was scheduled to be completed by March 1990 it had to be extended until March 2000 due to delays in meeting targets. While the GAP I was still in progress, the CGA introduced the GAP II, targeting pollution along the three major tributaries of the Ganges (Yamuna, Damodar, and Gomti) as well as in 25 Class I towns (urban agglomerations with a population of more than 100,000) that had been left out in the GAP I. The funding arrangement also changed during the GAP II where expenses were to be met equally by the central government and the five state governments involved [43].

\section{Gaps in the GAP}

Since enacting the Water Act of 1974, India has had the necessary environmental legislation for the protection of water resources. However, enforcement has been chronically deficient. Water resources in urbanized basins globally are under stress, and the Ganges is a most prominent exemplar. Clean up programs have had little success in checking pollution. For instance, according to the report published by the Comptroller and Auditor General of India, by the year 2000, the GAP had achieved only 39 percent of its proposed target for sewage treatment, consuming 91 percent of its budget allocation. The report also shed light on the discrepancies in the selection of cities and towns, allocation of funds based on inaccurate estimates of sewage load, and wide variation in the performance of different states in meeting GAP targets. Centralized resource management policies marginalized urban institutions and divested them of the power to manage sewerage and water services [44]. Most importantly, the GAP failed to create any kind of regional cooperation among the states that the Ganges passes through (Uttarakhand, Uttar Pradesh, Bihar, Jharkhand, and West Bengal) in addressing pollution at the basin level. In the following section, we discuss two key aspects of dealing with point and non-point source pollution - the top-down, technocratic approach of the GAP coupled with weak local government 
capacity and the lack of public participation - that highlight the tenuous relationship between the need for 'efficient' management of water resources and decentralization and citizen participation.

\subsection{A Top-Down, Technocratic Program}

The goal of the GAP in addressing point source pollution was straightforward: "intercept, divert, and treat" wastewater generated in urban centers. The organizational structure of the NRCA was hierarchical. It comprised five tiers, and state government involvement was limited to the lowest tier addressing the execution and maintenance of schemes. Despite a provision in the fourth tier for program development by the state governments, the central government was reluctant to share its power, so the role of state government agencies in the GAP projects was minimal. Almost all aspects of design and program development were done by the NRCA at the central level. State governments were assigned the task of setting up sewage treatment plants and targets, identifying polluters, and enforcing sanctions against violations [45]. GAP I was also entirely funded by the central government.

Local government institutions were missing from the organizational structure of the NRCA. The implementation of the GAP projects-setting up new sewage treatment plants, renovating existing plants, and expanding sewerage networks-was supposed to unfold at the local level. However, local governments were not consulted to assess their readiness to undertake the responsibilities in a timely fashion, nor were their inputs sought in the design and implementation of projects. Instead, the NRCA assumed that the funds disbursed to the municipalities by the central or state governments would ensure that sewage treatment targets were met [45]. Additionally, the NRCA did not make adequate provisions for monitoring the implementation process or for penalizing state or local governments for under-performance. There was very little accountability among state and local government institutions. For instance, local governments were not required to establish a revenue base for operation and maintenance. Although the NRCA monopolized all GAP related decision-making, the agencies deputed for implementing the projects were overwhelmed by the scale and scope of their duties. Besides being unfamiliar with on-the-ground realities in different locales, they lacked the human resources necessary to ensure effective implementation and monitoring [45].

Audit checks in the states revealed many instances of administrative delays leading to cost escalations, faulty designs of the schemes, dysfunctional contract management, and poor maintenance [43]. Notably, the GAP I set up sewage treatment plants that were not context-appropriate. Typically, wastewater treatment plants benefit from economies of scale; however, their operation and maintenance costs are high. They are also energy intensive, produce large quantities of excess sludge which must be disposed of, and require sophisticated equipment that need to be handled by well-trained and well-managed operators and engineers. Decisions about the expensive sewage disposal and treatment facilities were made by GAP officials in the capital city of Delhi, without taking into account local conditions, including the financial and management capacity of the municipalities that would be responsible for operating and maintaining the new infrastructure [45].

\subsection{A People's Program}

When it came to tackling non-point source pollution, the GAP professed to be a "people's program." However, critics have pointed out that participation in the GAP was symbolic rather than 
substantive. The government's approach to participation was manipulative - it supported participation mainly for political expediency [5]. For instance, at the launch of the GAP in Varanasi, the Ganges was described as the greatest symbol of national unity and its pollution was attributed to divisive forces in the country [5]. Participation was also limited to the more token forms such as sporadic ghat clean up campaigns and ghat-based street theater and concerts to involve Hindu pilgrims. Such events were based on volunteerism and did not create any lasting sense of ownership. Local governments were not involved and did not receive support from the center to promote public participation. Similarly, NGOs were expected to adopt the ghats and maintain them but they did not receive financial support for their work nor were they invited to participate in decision-making. Clearly, the focus of the GAP was on achieving targets and not on building partnerships with the local community. Although it did not lack the financial resources necessary for public participation, the bureaucracy was so goal-oriented that it was willing to overlook the importance of people's everyday relationship with the river. Participation simply meant creating "mass awareness" about pollution in the Ganges. It did not involve sharing information about the GAP and its goals with the public, much less inviting active decision-making, creative problem-solving, and shared prioritization, monitoring and assessment.

As Ahmed [5] points out, the government's top-down approach assumed that people are the problem, rather than the institutions. Most of the projects were, therefore, targeted towards people's interaction with the river. For instance, a police task force was created in Varanasi to monitor pollution along the river. Without public participation in making the decision, the creation of the river police force only exacerbated already strained relations between local government officials and the people [46], alienating the local community instead of getting them involved. Residents and pilgrims complained about being harassed by the police who were supposed to garner public support in the fight against pollution. Some of the residents we interviewed mentioned how the police had taken to petty corruption. They would dump dead bodies in the river and pocket the money they were paid by the municipal corporation for cremating unidentified bodies. The GAP allocated a small amount of funds to local NGOs for playing the role of intermediaries and mobilizing the local community. However, according to Ahmed [5], NGOs like the Sankat Mochan Foundation, which was actively involved in efforts to clean the Ganges, did not significantly represent the people it was trying to mobilize. In theory, the NGO was closer to the people than agency representatives, but their emphasis was on cultural and religious symbolism. For them, the local community was a homogeneous entity and they did not substantially question the distribution of power when it came to participation. But, in fact, different groups of people share a different relationship with the river. Issues of class, caste, and gender are interlinked and cannot be ignored. For instance, the dhobis (washermen) felt marginalized when the GAP threatened their occupational livelihood by restricting the washing of clothes along some stretches of the Ganges while allowing the yadavs (milkmen) to continue bathing their cattle [5].

Civil society-local and international NGOs, scholars and researchers, and religious leaders - played a crucial role in creating awareness and mobilizing public opinion about pollution in the Ganges. They did not allow the government to remain complacent about such problems and acted as watchdogs, exposing the shortcomings of the GAP projects [45]. For instance, the Sankat Mochan Foundation was able to form global alliances to help them put pressure on the government. However, despite growing civil society involvement with the GAP, public participation was very weak and 
according to the Comptroller and Auditor General of India (CAG) [43], at the end of the program the budget earmarked for it remained under-utilized. Although the CAG emphasized the need for public participation, particularly of those living on the banks of the Ganges and of community based organizations (CBOs) and NGOs through wider publicity of the project, the NRCD and the respective state governments ignored these suggestions [43]. Consequently, the GAP I never garnered public support. The technocratic approach to problem solving only created fragmented, expensive systems of expertise [5]. Whether by design or ignorance, GAP I officials side-stepped possibilities for the generation of shared knowledge and recognition of the validity and worth of local people's perspectives about the Ganges as a sustaining resource and a sacred entity intricately tied to their daily lives.

\section{Moving Forward: What Needs to Be Done Differently?}

In November 2008, the Prime Minister of India declared the Ganges a National River and set up the National Ganga River Basin Project (NGRBP) for its clean up. A \$1 billion loan from the World Bank was approved in 2011. Recognizing the past failure of clean up projects of which the GAP was the most prominent, the NGRBP emphasizes the need for effective water resources management. The NGRBP will be the first basin-level initiative in India to manage an inter-state river for water quality and environmental protection [47]. According to the World Bank [47], "successful river clean up requires supporting urban services." The project goals, therefore, confront the challenges of urban governance and highlight the role of the Jawaharlal Nehru National Urban Renewal Mission (JNNURM) in strengthening the capacity of urban local bodies for infrastructure improvements. The JNNURM is a massive program that shifts the attention of national policies to urban development. According to its mission statement, "the aim is to encourage reforms and fast track planned development of identified cities. Focus is to be on efficiency in urban infrastructure and service delivery mechanisms, community participation, and accountability of urban local bodies/parastatal agencies towards citizens" [48]. The program hinges on a carrot-and-stick approach, providing federal funds to select cities conditional upon their agreement to undertake governance reform to become efficient [49]. The primary objectives of the NGRBP are to build the capacity of local institutions to manage a comprehensive Ganges clean up and conservation program, and to reduce point source pollution loads through sustainable interventions at selected locations [47]. The project takes a somewhat different approach than the GAP by positioning itself broadly within an IWRM framework with a focus on the land-water interface. The question then is: what can be done differently to avoid the hurdles encountered and disappointments generated by the GAP? Can the overarching goals of the NGRBP to restore the river's health also help preserve people's age-old relationship with the holy river? In the next section, we explore these questions and provide insights about what future clean up programs might entail.

\subsection{Water Quality and Environmental Protection}

The key to effective pollution control programs in the Ganges basin lies in clearly differentiating between point and non-point source pollution and their removal. While checking point sources such as municipal sewage calls for major institutional reform along with the use of context-appropriate 
treatment technology, tackling the seemingly intractable non-point sources could benefit from a participatory approach involving all stakeholders. River basin management and urban water quality programs aimed at non-point sources, many of which are tied to the religious significance of the river, should focus on building partnerships and sustainable relationships, at the core of which should be representative and collaborative state, civil society, and the private sector. The GAP never remotely achieved this ideal. However, the NGRBP, which takes into account the shortcomings of the GAP, could provide an opportunity to work collectively to resolve the non-point source pollution while respecting those aspects of people's relationship with the river that are profound and sacred.

The GAP attempted to tackle point sources of pollution by setting up sewage treatment plants near major urban centers along the Ganges. However, past experience with the GAP in Varanasi, for instance, has shown that besides being energy intensive, the capacity of the sewage treatment plants was inadequate for the amount of sewage generated. Moreover, erratic power supply often rendered them nonfunctional for long periods. During the monsoon season, the sump wells flooded, and pumping stations would shut down for months, allowing untreated sewage to be released directly into the river. Our interviews revealed that NGOs such as the Sankat Mochan Foundation in Varanasi were not convinced that installing such plants, which use activated sludge technology, was an appropriate choice. To back their claims, they conducted tests which showed that water quality at different locations in Varanasi, despite the interventions, remained drastically short of the standards considered safe for religious bathing; indeed, at places like the Varuna-Ganga confluence, the water was septic (practically no dissolved oxygen to support bacterial digestion). It is well established that major point source pollution such as ineffective municipal sewage plants are among the most pressing problems associated with urbanization in the Ganges basin. In fact, municipal sewage forms the bulk of the pollution load. One of the goals of the NGRBP, therefore, is to ensure that by 2020 no untreated municipal sewage or industrial effluents is released into the Ganges. What needs to be done differently when dealing with point source pollution, then, is to address the larger issue: the lack of urban environmental services such as water supply, sewage systems, and solid waste disposal in cities along the Ganges. Until the provision of such services receives the attention it deserves, cleaning the Ganges will face serious setbacks. As with most urban centers in India, the infrastructure in Varanasi varies from substandard to non-existent in poorer sections of the city. Neighborhoods such as Sarai Mohana and Gola Ghat lack both sewerage and piped water supply and have a high incidence of waterborne/enteric diseases, which is associated with their water use patterns [38]. Overall, urban sanitary infrastructure is in dire need of renewal. Urbanization, primarily through unplanned inmigration of rural poor looking for employment, has also seen the proliferation of slum settlements lacking access to basic services. The effectiveness of sewage treatment plants is often compromised when untreated wastewater from households that are not connected to the sewage infrastructure flows into open drains and find its way into the river. Addressing this vast and spatially dispersed, yet locally idiosyncratic, problem will put much of the onus on local governments.

India's 74th Constitutional Amendment Act (CAA) of 1992 states that urban local bodies (ULBs) are responsible for the operation and maintenance of urban water supply for domestic, industrial, and commercial purposes and their functions are enumerated in the Twelfth Schedule of the Constitution. Although the CAA sought to strengthen municipal governance by devolving power to ULBs, so far decentralization has remained piecemeal in most cases. Smaller ULBs are often faced with problems of 
fiscal decentralization not keeping pace with administrative decentralization and with the lack of capacity, forcing them to rely on projects designed and funded by state agencies. However, some municipalities have turned to public-private partnerships for the provision of basic services with favorable outcomes. Such partnerships involve service contracts, where the government remains the primary provider of the service and contracts out parts of its operation to a private company to reduce operating costs. The government pays the private company a predetermined fee for its services and deals with any capital investments needed to improve or expand the system. For instance, in Chennai, the Metro Water Supply and Sanitation Board contracted out the operation and maintenance of sewage treatment plants and pumping stations, which resulted in savings of more than 20 percent [50]. ULBs could also search for alternative technologies that are low cost and more context-appropriate to replace capital and energy intensive technology that requires a high level of expertise for operation and maintenance. For instance, in Varanasi, the Sankat Mochan Foundation has been working with engineers at the University of California, Berkeley, who developed Advanced Integrated Wastewater Pond Systems as an alternative to conventional sewage treatment plants [51]. The Varanasi Municipal Corporation unanimously approved the system in 1997, but funding for installing pilot systems has only recently been approved by the central government as part of the NGRBP.

The GAP focused on finding technocratic solutions to improve water quality. What received less attention was water quantity and the need to maintain ecological flows in the river at all times. The NGRBP recognizes the importance of both water quality and environmental protection [47]. However, it is important to stress here that since the Ganges is a holy river, any clean up program has to acknowledge the prevalent religious and cultural beliefs held by pilgrims and entrepreneurs along its banks and the many Hindu adherents throughout India. In this regard, both water quality and quantity need consideration. Without the required assimilative capacity, practices such as religious bathing cannot be sustained. This, in turn, is tied to the broader issue of competing water uses, where the pressure to generate hydroelectric energy for development is in conflict with maintaining hydro-ecosystematic services [52]. Climate change-induced impacts to regional hydrological patterns are already exacerbating water quantity problems. The old mindset of assigning value to water resources only when they can be exploited desperately warrants change. The need to recognize the value of ecosystems when allocating water and to maintain the minimum flows required for ecological integrity in riverine and riparian environments has been emphasized time and again at international conferences and commissions. However, water policies in India consistently favor the supply side. In most urban centers, both surface and groundwater sources are severely degraded. Municipalities, therefore, seek new sources to meet the growing demand for water supply [53]. These sources are often located far away and developing them can incur high capital costs and result in wasteful distribution losses. Since such costs cannot be transferred easily to users, municipalities are not able to generate the revenues required to operate and maintain such systems. To help focus on minimizing waste and encouraging conservation so that appropriate base flows are maintained in the Ganges, the introduction of caps on withdrawals need to be considered in the Ganges basin. As Postel [54] points out, setting boundaries and caps, when based on good scientific knowledge, need not be "anti-development but rather pro-sustainable development." Such an approach calls for cooperation across national, regional, and local levels of government and civil society. 


\subsection{Public Participation}

The GAP largely ignored public participation despite having funds allocated for it. It is interesting to note, therefore, that the NGRBP has made provisions for public participation although it has not yet outlined how it is to be implemented [47]. Large-scale environmental problems, like that occurring in the Ganges basin, stem from a vast and complex array of point and non-point source pollution. Unlike point source pollution, the root causes of the non-point source pollution are mostly socio-political, economic and religious and cannot be handled exclusively by experts. They can, however, be addressed by creating institutional spaces that promote collaboration and public participation. If clean up projects rely on the public simply to monitor and implement regulations that have been set by others, as done by the GAP, they are unlikely to tap into local knowledge about the state of the Ganges. Moreover, it is important to kindle a sense of local ownership and acceptability. Involving both the residents of Varanasi and pilgrims in the governance of the resource, therefore, means that they participate in setting the rules, in determining sanctions, and in other issues related to the management of the resource. The founder of the Sankat Mochan Foundation, who is a religious leader and a civil engineer, recalled his own struggle in reconciling the contradictions between "scientific" and "traditional" views. In our interview, he pointed out that religious rituals could become an important cultural code of resource management that people are more likely to respect than any other law. He said, "people are hurt when anyone says that the Gangaji is polluted. For instance, if I start speaking at a public meeting and if I keep emphasizing how polluted the river is, then probably someone from the audience will stop me. But if I say to the same congregation, come see what has been done to the Asi nalla [an open drain], which was a river at one point of time, and what it is doing to our mother — raw sewage being poured on her body, then the response will be different."

Although policy makers have dominated environmental decision-making, since the 1990s there has been a growing recognition and support for the participation of non-elites [55]. According to Holmes and Scoones [55], ordinary citizens should play a more decisive role in environmental policy making. In the global South, deliberative inclusionary processes for environmental policy making have been used as 'soft infrastructure' based on a model of social collaboration and learning. Various mechanisms such as citizen's panels, committees, focus groups, public meetings, visioning and scenario-building exercises, and workshops have been used to promote participation in environmental policy decisions [55]. Traditionally, pollution control relies on structural rather than non-structural processes. However, structural processes are insufficient given the growing complexity and uncertainty characteristic of contemporary water resources challenges, particularly non-point source pollution. The focus is, therefore, on moving towards building adaptive cross-sectoral capacities accommodating both new and traditional forms of knowledge to address the changing dynamics of social-ecological systems [56]. The process of social learning is a way of enhancing stakeholder participation. According to Pahl-Wostl et al. [57], there is a lack of understanding of the interactions between ecological systems and governance and cultural systems. Social learning provides the link between the two systems by developing relational capacities among stakeholders on how to collaborate. Stakeholders enter the process with different views and knowledge. They then go through deliberation, reflection, and learning to merge into collectively held views and a shared diagnosis of the problems. 
A growing body of literature contends that the most effective way for ordinary citizens to be represented is through culturally-sensitive NGOs and CBOs that can articulate their needs and priorities [58]. However, concern has been expressed about the extent to which such organizations can ever be truly representative [55,5]. In the case of the Ganges, some have proposed public participation through "Ganga Panchayats", based on the rural model of local self-governance in India, that would provide a deliberative platform for members of civil society [59]. Such a space would help pool local knowledge about the Ganges while allowing ordinary citizens to play a role in the planning and adaptive management process. While this appears to be a step in the right direction, it is important to exercise caution in moving forward. Public perceptions about environmental problems are often driven by biases and based on anecdotal evidence, and thus their validity has been challenged. The focus, therefore, might better shift toward a balanced approach that combines local knowledge and scientific information within a democratic political process [60]. Scholars have also highlighted the importance of environmental learning by developing 'knowledge building communities,' which can empower through horizontal learning approaches linking community concerns [61]. According to Hoadley et al. [61], such an approach tends to be much more conducive to indigenous knowledge and local practices while reconciling potential conflicts with exogenous perspectives (e.g., Western science). This is particularly relevant in the context of the Ganges where the knowledge building communities approach could provide a more nuanced understanding of the riverine ecosystem. It could also help integrate larger scale ecosystems management with decentralized, yet networked, political-administrative systems.

Unlike the GAP, the NGRBP has incorporated basin-level planning, which makes public participation an important component. However, simply embracing the vocabulary of participation does not ensure that it will be successfully implemented. Countries across the world have adopted progressive, participatory water governance. For instance, in 1998, the National Water Act of South Africa established water as a national resource, owned by the people of South Africa. The law established a Water Reserve to ensure water allocation to meet basic human needs and to support ecosystem functions. The Water Reserve is guaranteed as a right and has priority over licensed users. The law also outlined provisions for the creation of catchment management agencies responsible for drawing up a management strategy for the catchment and emphasized community participation [54]. Similarly, the European Water Framework Directive has recognized the role of citizens and citizens' groups as a crucial component of cleaning their waters, the main objectives being to arrive at the appropriate measures by balancing the interests of various groups and to ensure enforcement. The Directive requires information and consultation when river basin management plans are developed [62]. However, not all countries are able to successfully implement such programs, which depends, to a large extent, on the availability of resources and capacity. The NGRBP is an ambitious program that intends to overcome the shortcomings of the GAP in this regard but its litmus test lies in its implementation. No one agency is equipped with the financial and human resources necessary to check non-point source pollution. Enforcement of regulation can be expensive, which makes it necessary to encourage voluntary action. Partnerships with the private sector, community based organizations, and users of the waterfront, will, therefore, be crucial to support monitoring as well as assessment to evaluate the success of efforts to prevent pollution. Moreover, dissemination of information about water quality and actions to prevent pollution will be essential in cementing the 
long-term cooperation of all stakeholders. Without addressing some of the fundamental institutional problems associated with the provision of basic municipal services and enlisting the help of civil society groups to tackle non-point source pollution, the NGRBP faces the danger of falling into the same trap as its predecessor.

\section{Conclusions}

The Ganges has been accorded the status of National River. For several millennia it has occupied a special place in the sacred landscape of the country, and it will continue to do so well into the future. However, over the years, pressures of urbanization, accompanied by the growing threat of pollution, have called for serious attention. Pollution control programs - GAP I in 1985 and GAP II in 1991—have attempted to clean the Ganges but have had little success. Projects under the GAP were woefully behind schedule and incurred major cost overruns. While the GAP was clear in terms of its goals, it suffered from a top-down, technocratic approach to problem solving, lacked resources and institutional capacity as well as public participation. It was solely planned and designed by the CGA, with the NRCA as the apex body in a hierarchy of central government agencies. The role of state and local governments was reduced to implementation, operation and maintenance. Institutional complexity left little room for accountability. At the central government level, the GAP created different monitoring agencies with overlapping roles and responsibilities. Even in terms of implementation, there was little coordination between State Pollution Control Boards and municipalities. Historically, environmental policy making in India has been confined to a highly centralized planning approach. State governments, local governments and stakeholders (NGOs, the private sector, and citizens) have not played a decisive role in shaping environmental policies and a culturally sensitive, place-based perspective on riparian urbanism [63] has been lacking on all fronts. Although the Ganges flows through five states, there are no regional agencies to foster cooperation at a basin level.

In analyzing the GAP and looking at future directions for pollution control programs in the Ganges basin, it is important to point out some of the broader shifts in the policy arena that have taken place over the last decade or so that are pertinent to creating spaces for public participation in water governance. Firstly, there is decentralization, which seeks to bring decision-making closer to the people and promote participation. It has the potential to initiate a shift from the traditional goal-oriented approach in environmental planning to one that is process-based. The GAP unfolded in an institutional context where decentralization was a relatively new concept and, in many states, the transfer of power to lower levels of government had not yet materialized. Although it is true that, overall, central and state governments have been reluctant to devolve decision making to local governments, resulting in weak decentralization (with the exception of some states), the 73rd and 74th CAA encourage collaboration by creating space for public participation. Utilizing this space particularly in dealing with non-point sources of pollution is truly important in the case of the Ganges where people's everyday relationship with the river cannot be overlooked in shaping policy. Moreover, since the completion of the GAP, the institutional landscape in India has also witnessed much change. Local government institutions have been engaged in capacity building and, in many cases, they have been able to reap the benefits of public-private-partnerships in the management of urban services. 
Secondly, the Right to Information Act of 2005 marks a watershed, providing ordinary citizens access to information. Its goal is to ensure transparency and accountability in the working of every public authority [64]. This promises to substantially bolster public participation in shaping environmental policy. It could also strengthen the pivotal role of civil society in environmental stewardship. The media and the internet are already contributing towards increasing environmental awareness and participation among the public. For instance, in the UK, participatory GIS is used to assess air quality and improve local government policy [65]. Social media is also serving a key role in enforcing informal regulation [45]. In India, NGOs have been instrumental in putting pressure on the government through advocacy, monitoring, and raising awareness. For instance, in Varanasi, the Sankat Mochan Foundation has been particularly effective in drawing national and international attention to the flawed planning and mismanagement of the GAP programs [45]. It is now working in collaboration with GO2 Water, a California based firm, to build a pilot system that will treat 37 million liters of wastewater per day. The system, called the Advanced Integrated Wastewater Pond System, consists of a series of ponds that help to break down organic matter and remove fecal bacteria. It minimizes the amount of sludge generated (relieving the burden of disposal) and has a relatively lower cost of operation than traditional wastewater treatment systems.If it is successful, such systems will be installed in other cities along the Ganges [66]. Clearly, representatives of civil society can play a crucial role in realizing participatory environmental management strategies. However, catalyzing public participation to influence environmental decision-making has to be a collaborative endeavor. It requires both institutional and financial support from the government and cannot be undertaken by civil society alone.

Given the current urbanization trends and population pressures in the Ganges basin, achieving a clean-flowing Ganges and regenerating the riverine ecosystem is bound to be a gargantuan task. Public participation - and even acts of civil disobedience such as G.D. Agrawal's recent hunger strike to save the Ganges [67] — could pave the way for more effective programs. At the same time, there is much work to be done in terms of building adaptive capacity. Future pollution control programs like the NGRBP should take into account lessons offered by past clean up programs. The one lesson that clearly stands out is the need to build partnerships with the people who share a symbiotic relationship with the Ganges and the imperative of bridging the divide between science and the sacred.

\section{Acknowledgements}

Fieldwork in Varanasi undertaken by the first author was funded by the Alma Heinz and August Pohland Graduate Scholarship and the Institute for Arts and Humanities, Penn State University.

\section{Conflict of Interest}

The authors declare no conflict of interest. 


\section{References and Notes}

1. Ministry of Home Affairs. Census of India, 2001; Government of India: New Delhi, India, 2001. Available online: http://censusindia.gov.in/ (accessed on 24 July 2012).

2. Sampat, P. Ganges' long decline. World Watch 1996, 9, 24-32.

3. Mehta, S. Visible city. Metropolis 1998, 17, 53.

4. Mishra, V.B. Department of Civil Engineering at the Institute of Technology, Banaras Hindu University, Varanasi, India. Personal Communication, 2000.

5. Ahmed, S. The rhetoric of participation re-examined: The state, NGOs, and the water users at Varanasi, Uttar Pradesh, India. Environ. 1994, 14, 3-16.

6. Smoke, P. Fiscal Decentralization in Developing Countries: A Review of Current Concepts and Practice; UNRISD: Geneva, Switzerland, 2001.

7. Manor, J. The Political Economy of Democratic Decentralization; The World Bank: Washington, DC, USA, 1999.

8. Rondinelli, D.A.; Cheema, S. Implementing Decentralization Policies: An Introduction. In Decentralization and Development: Policy Implementation in Developing Countries; Cheema, S., Rondinelli, D.A., Eds.; Sage Publications: Beverley Hills, CA, USA, 1983.

9. Rondinelli, D. What is Decentralization? Decentralization Briefing Notes; World Bank Institute Working Papers; Litvack, J., Seddon, J., Eds.; The World Bank: Washington, DC, USA, 1999.

10. Litvak, J.; Ahmad, J.; Bird, R. Rethinking Decentralization in Developing Countries; The International Bank for Reconstruction and Development (IBRD): Washington, DC, USA, 1998.

11. Crook, R.; Sverrisson, A. Decentralization and Poverty Alleviation in Developing Countries: A Comparative Analysis, or, is West Bengal Unique?; Institute of Development Studies Working Paper No. 130; Institute of Development Studies: Brighton, UK, 2001.

12. Tendler, J. Good Government in the Tropics; Johns Hopkins University Press: Baltimore, MD, USA, 1997.

13. Cornwall, A.; Gaventa, J. From users and choosers to makers and shapers: Repositioning participation in social policy. IDS Bull. 2001, 3, 50-62.

14. Ostrom, E. Governing the Commons: The Evolution of Institutions for Collective Action; Cambridge University Press: Cambridge, UK, 1990.

15. Baviskar, A. Between micro-politics and administrative imperatives: Decentralization and the watershed mission in Madhya Pradesh, India. Eur. J. Dev. Res. 2004, 16, $26-40$.

16. Manor, J. User committees: A potentially damaging second wave of decentralization? Eur. J. Dev. Res. 2004, 16, 192-213.

17. Larson, A. Formal decentralization and the imperative of decentralization 'from below': A case study of natural resource management in Nicaragua. Eur. J. Dev. Res. 2004, 16, 55-70.

18. Brannstrom, C. Decentralizing water resources management in Brazil. Eur. J. Dev. Res. 2004, 16, 214-234.

19. Blair, H. Participation and accountability at the periphery: Democratic local governance in six countries. World Dev. 2000, 28, 21-39.

20. 'Wicked problems' are problems of interrelationships between biophysical, human, and economic systems that cannot be resolved by isolating any single factor. 
21. Gunderson, L.H.; Holling, C.S.; Light, S.S. Barriers and Bridges to the Renewal of Ecosystems and Institutions; Columbia University Press: New York, NY, USA, 1995.

22. Pahl-Wostl, C. The implications of complexity for integrated resources management. Environ. Model. Softw. 2007, 22, 561-569.

23. Global Water Partnership (GWP). Integrated Water Resources Management; Technical Advisory Committee Background Paper No. 4; GWP: Stockholm, Sweden, 2000.

24. Feldman, D.L. Water Policy for Sustainable Development; Johns Hopkins University Press: Baltimore, MD, USA, 2007.

25. Brugnach, M.; Ingram, H. Ambiguity: The challenge of knowing and deciding together. Environ. Sci. Policy 2012, 15, 61-70.

26. Allan, C.; Curtis, A. Nipped in the bud: Why regional scale adaptive management is not blooming. Environ. Manag. 2005, 36, 414-425.

27. Biswas, A.K. Integrated water resources management: A reassessment. Water Int. 2004, 29, 248-256.

28. Biswas, A.K. Water policies in the developing world. Int J. Water Resour. D. 2001, 17, 489-499.

29. Hosterman, R.H.; McCornick, P.G.; Kistin, E; Sharma, B.; Bharati, L. Freshwater, climate change and adaptation in the Ganges River Basin. Water Policy 2011, 14, 67-79.

30. National Council for Geographic Information. Cleaning up the Ganges River. Available online: http://ncge.co/2011/09/30/cleaning-up-the-ganges-river/ (accessed on 24 July 2012).

31. Eck, D.L. Banaras: City of Light; Knopf: Princeton, NJ, USA, 1983.

32. Ray, R. Ghats of Mathura and Vrindavan. Architecture \& Design 1989, 16, 61-69.

33. Sinha, A. Nature in Hindu art, architecture and landscape. Landsc. Res. 1995, 20, 3-10.

34. Parry, J. Death in Banaras; Cambridge University Press: Cambridge, UK, 1994.

35. Central Pollution Control Board (CPCB). Annual Report 1999-2000; Government of India: New Delhi, India, 2000.

36. On environment day, Ganga continues to bear increasing pollution. The Times of India. Available online: http://articles.timesofindia.indiatimes.com/2012-06-06/pollution/32077802_1_gangadussehra-ganga-action-plan-holy-river (accessed on 15 July 2012).

37. Fecal coliform count (FCC) is the most probable number of bacterial colonies in a water sample. Fecal coliform are a bacteria found in feces of humans and other animals; their presence in large numbers indicates pollution by sewage contamination. Biological oxygen demand (BOD) is the amount of oxygen used by microorganisms to break down organic matter.

38. Hamner, S.; Tripathi, A.; Mishra, R.K.; Bouskill, N.; Broadaway, S.C.; Pyle, B.C.; Ford, T.E. The role of water use patterns and sewage pollution in waterborne/enteric diseases along the Ganges river in Varanasi, India. Int. J. Environ. Health Res. 2006, 16, 113-132.

39. Alley, K.D. Ganga and gandagi: Interpretations of pollution and waste in Benaras. Ethnology 1994, 33, 127-145.

40. Personal communication with a Varanasi resident, Varanasi, India, January, 2000.

41. Dwivedi, O.P. India's Environmental Policies, Problems and Stewardship; St. Martin's Press: New York, NY, USA, 1997.

42. Ministry of Environment and Forests. Annual Report 1995-1996; Government of India: New Delhi, India, 1996. 
43. The Comptroller and Auditor General of India (CAG). Report no. 5A of the CAG on the Union Government: Ganga Action Plan; Government of India: New Delhi, India, 2000. Available online: http://saiindia.gov.in/english/home/Our_Products/Audit_Report/Year_Wise/All_Yearwise_ Reports/2000.html (accessed 15 January 2012).

44. Alley, K.D. Urban institutions at the crossroads: Judicial activism and pollution prevention in Kanpur. Urban Anthropol. 1996, 24, 351-383.

45. Das, A.; Das, P. Institutional Change for Environmental Challenges: Lessons from Gaps in the GAP. In Environment: Problems and Policies; Gupta, K.R., Ed.; Atlantic Publishers \& Distributors: New Delhi, India, 2005; Volume 2.

46. Stille, A. The Ganges' next life. The New Yorker. 19 January 1998, 58.

47. World Bank. India-National Ganga River Basin Project; Report No. AB6013; World Bank: Washington, DC, USA, 2011; Volume 1.

48. Ministry of Urban Development. Jawaharlal Nehru National Urban Renewal Mission. Available online: http://jnnurm.nic.in (accessed on 20 January 2012).

49. Sivaramakrishnan, K.C. Re-visioning Indian Cities: The Urban Renewal Mission. Sage Publications: New Delhi, India, 2011.

50. Sansom, K.; Franceys, R. Private sector participation in WATSAN services. In Proceedings of 23rd WEDC Conference: Water and Sanitation for all: Partnerships and Innovations; Durban, South Africa, 1-5 September 1997.

51. Varanasi: A model city. Available online: http://cleanganganow.org/clean-ganga-vision/pilottechnology-in-varanasi/ (accessed on 24 July 2012).

52. The Ministry of Environment and Forests has signed a Memorandum of Understanding with a consortium of seven educational institutions (Indian Institute of Technology) to conduct a cumulative environmental impact assessment and recommend what needs to be done to maintain minimum ecological flows. Available online: http://www.moef.nic.in (accessed on 20 January 2012).

53. In Indore, water supply for the city is to be brought in from the Narmada river, $70 \mathrm{~km}$ away.

54. Postel, S. Liquid Assets: The Critical Need to Safeguard Freshwater Ecosystems; Worldwatch Institute: Washington, DC, USA, 2005.

55. Holmes, T.; Holmes, I. Participatory Environmental Policy Processes: Experience from the North and South; IDS Working Paper 113; Institute of Development Studies, University of Sussex: Brighton, UK, 2001, pp. 51-55.

56. Folke, C.; Hahn, T.; Olsson, P.; Norberg, J. Adaptive Governance of Social-ecological Systems. Annu. Rev. Environ. Resour. 2005, 30, 441-73.

57. Pahl-Wostl, C.; Mostert, E.; Tabara, D. The growing ilmportance of social learning in water resources management and sustainability science. Ecol. Soc. 2008, 1, 24.

58. Zazueta, A.E. Policy Hits the Ground: Participation and Equity in Environmental Decision-Making; World Resources Institute: Washington, DC, USA, 1995.

59. Kumar, A. Government urged to form Ganga panchayats. The Times of India. Available online: http://articles.timesofindia.indiatimes.com/2011-06-08/patna/29633402_1_ganga-river-gangaghats-river-land (accessed on 24 July 2012).

60. Warner, M. 'Consensus' participation: An example for protected areas planning. Public Adm. Dev. 1997, 17, 413-432. 
61. Hoadley, C.; Honwad, S.; Tamminga, K. Technology-Supported Cross-Cultural Collaborative Learning in the Developing World. In Proceedings of the ICIC 2010 International Conference on Intercultural Collaboration; Copenhagen, Denmark, 19-20 August 2010; ACM Digital Library: Copenhagen, Denmark, 2010; pp. 131-139.

62. European Commission. Introduction to the new EU Water Framework Directive, 2007. Available online: http://ec.europa.eu/environment/water/water-framework/info/intro_en.htm (accessed on 20 January 2012).

63. The riparian urbanism perspective seeks to interweave urban and hydro-ecological functions and patterns within sustainable cityscapes and bioregions. It recognizes and protects riparian ecosystem services, and calls for ample space for riparian and aquatic processes and organisms strongly connected to larger biophysical systems. At the same time, it sees urban riparia through an urbanist lens. It celebrates the city-water interface as an ordering network, an essential counterpoint to built form, and an accessible source of sustenance, conviviality, and inspiration for the life of the city.

64. Government of India. Right to Information. Available online: http://righttoinformation.gov.in/ (accessed on 24 July 2012).

65. Cinderby, S.; Forrester, J. Facilitating the local governance of air pollution using GIS for participation. Appl. Geogr. 2005, 25, 143-158.

66. Stone, R. A remedy at last for the ailing Ganges? Science 2011, 332, 412-413.

67. National Geographic. Water Currents. Available online: http://newswatch.national geographic.com/2012/03/16/dying-for-the-ganges-a-scientist-turned-swami-risks-all (accessed on 28 March 2012).

(C) 2012 by the authors; licensee MDPI, Basel, Switzerland. This article is an open access article distributed under the terms and conditions of the Creative Commons Attribution license (http://creativecommons.org/licenses/by/3.0/). 